\title{
DEVELOPMENT AND PERFORMANCE EVALUATION OF THE DOUBLE TINES SUBSOILER IN SILTY CLAY SOIL PART 1: DRAFT FORCE, DISTURBED AREA AND SPECIFIC RESISTANCE
}

M. N. Ramadhan

Machines and Agricultural Machineries Dept./ Agric. College/ Basrah University/ Basrah/ Iraq.

malali841@gmail.com

\begin{abstract}
The objectives of this investigation were to investigate the effects of plowing depths (D) $(35,45,55$, and $65 \mathrm{~cm})$, forward speeds $(\mathrm{S})(0.341,0.551$ and $0.761 \mathrm{~m}$ $\mathrm{sec}^{-1}$ ) and outfitted subsoiler foot with wings on equipment performance for two subsoiler shanks arrangement (oblique and parallel) in silty clay loam soil. A significant $(\mathrm{p}<0.01)$ decrease in draft and specific resistance were observed for oblique shank arrangement compared with parallel shank arrangement. Furthermore, the draft and disturbed area increased significantly $(\mathrm{p}<0.01)$ with increasing operating depth, whereas specific resistance decreased significantly $(p<0.01)$ with depth for the oblique and parallel shanks arrangement respectively. The values of draft, disturbed area and specific resistance of the oblique and parallel shanks arrangement tested were affected significantly $(\mathrm{p}<0.01)$ by adding wings to subsoiler feet. Forward speeds had a significant $(p<0.01)$ effect on studded parameters. The optimal performance were found with the forward speed of $0.341 \mathrm{~m} \mathrm{sec}^{-1}$.

Keywords: Draft, Disturbed Area, Specific Resistance, Wings, Forward Speed, Path Coefficient.
\end{abstract}

Received : 14/12/2011 Accepted : 15/10/2012

\section{INTRODUCTION}

Deep tillage operations are required to alleviate compaction layers and hardpans often found in the southern parts of Iraq. Subsoilers are common implements used to break the compaction layer and hard pans found in these soils. A high-energy input is required to disrupt hardpan layer to promote improved root development and increased drought tolerance. Therefore, draft requirements are important in order to determine the size of the tractor that could be used for a specific implement. The typical draft requirements depend on the working depth, tool geometry, travel speed, width of the implement and soil properties (Gill and Vanden Berg, 1968, Palmer and Kruger, 1982, Upadhyaya et al., 1984, ASAE, $\left.1999^{\mathrm{a}}\right)$. Godwin and Spoor (1977) determine the draft requirement of subsoiler, they found that the draft consumed by subsoiler plow increased with the increase in depth. Increasing the depth from 30.3 to $40.5 \mathrm{~cm}$ increased the draft from 28.85 to $42.36 \mathrm{kN}$. Drever and Wiens (1980) summarized the performance data in an attempt to permit a logical comparison of four tillage performance (Kello-Bilt \#1824 single bottom plow, Three-layer Plow, Wheel plow and Kello-Bilt subsoiler), the tillage speed and depth was $5 \mathrm{~km} \mathrm{~h}^{-1}$ and $0.6 \mathrm{~m}$ respectively. The draft was 62, 53, 52 and $119 \mathrm{kN}$ for the previous equipments respectively. Iqbal et al. (1994) determined the

draft requirement of selected primary and secondary tillage implements in a silty loam soil using the field speed of $2.5 \mathrm{~km} \mathrm{~h}^{-1}$, they found that the draft consumed by chisel plow increased linearly with the increase in depth of 
cultivation. Desbiolles et al. (1997) found that the draft required for subsoiler outfitted with wings in sandy loam soil increased from 6.37 to $11.5 \mathrm{kN}$ with increasing plowing depth from 30 to $40 \mathrm{~cm}$. Al-Suhaibani and Ghaly (2010) mentioned that chisel draft force increased from 3.14 to $8.33 \mathrm{kN}$ and soil volume increased from 0.18 to $0.36 \mathrm{~m}^{3}$ as operating depth increased from 11 to $23 \mathrm{~cm}$ in sandy loam soil, they also found, when working at $23 \mathrm{~cm}$ depth, that draft force of chisel plow increased from 8.33 to $11.92 \mathrm{kN}$ when the forward speed increases from 0.75 to $2.30 \mathrm{~m} \mathrm{sec}^{-1}$.

Many authors proved that the draft increased by adding wings to subsoiler foot. In an experiment conducted by Godwin et al. (1981) they found that adding wings of $10 \mathrm{~cm}$ width to subsoiler foot led to increasing draft from about 10 to $15 \%$ for four operating depth $25,42,46$, and $58 \mathrm{~cm}$, they also concluded that total force increases in an essentially linear manner with increasing forward speed. In the same direction Ahmed and Godwin (1983) conducted a research work on a compacted soil to study the influence of wing position on subsoiler penetration and soil disturbance. They found that draft increased from 15.9 to $22.8 \mathrm{kN}$ when adding wings of $30 \mathrm{~cm}$ width to the foot.

It has been also reported that draft on tillage tools increases significantly with speed and the relationship varies from linear to quadratic (Grisso et al., 1996). However, Glancey et al. (1996) found that speed effects on draft of tine to be less significant as compared to the effect of depth. The effect of speed on implement draft is further dependant on the soil type and that of the implement. In a study conducted by Chen et al. (1997) on the mole plow they found that draft increases with the increase in forward speed. In sandy loam soil conditions kichler et al. (2008) found that a KMC Generation I Rip-Strip subsoiler operating at 13-14 Inches depth required $7.295 \mathrm{Ibs}$ at $1.8 \mathrm{~m} \mathrm{~h}^{-1}$ forward speed and $10.017 \mathrm{Ibs}$ at $5.0 \mathrm{~m} \mathrm{~h}^{-1}$ forward speed. The effects of operating depth on disturbed area were reported by McKyes and Maswaure (1997). They found that disturbed area increased from 0.0207 to $0.0427 \mathrm{~m}^{2}$ by increasing the depth from 10 to $20 \mathrm{~cm}$ in clayey soil.

Spoor and Godwin (1978) concluded that disturbed area increased by $187.356 \%$ when adding wings to subsoiler foot. They also added that using subsoiler outfitted with wings width of $30 \mathrm{~cm}$ doubled the disturbed area while the draft force increased by $30 \%$. In addition the specific resistance decreased by adding wings to subsoiler foot from 459 to $175 \mathrm{kN} \mathrm{m}^{-2}$ in silty clay soil at $42 \mathrm{~cm}$ operating depth. Ahmed and Godwin (1983) pointed out that the disturbed area increased by adding wings to the subsoiler foot from 0.124 to $0.219 \mathrm{~m}^{2}$ at $36 \mathrm{~cm}$ operating depth in compacted alluvial unclassified soil. Di Prinzio et al. (1997) studied different conformations of deep tillage tools and resulted in an increase of $47 \%$ of the disturbed area by adding wings to the bottom of a conventional subsoiler. Stafford (1979) reported that the disturbed area increases with increasing forward speed, but this increase is minor compared with the increase in draft force. The amount of the disturbed area increases by $60 \%$ as the forward speed increases from 1 to $5 \mathrm{~m} \mathrm{sec}^{-1}$ in sandy soils. In clay soils did not show an effect of speed on the disturbed area.

The operating depth has prominent effect on specific resistance by increasing the disturbed area. Misao (1992) indicated that specific resistance decreased from 50 to $40 \mathrm{kN} \mathrm{m}^{-2}$ as the operating depth increased from 20 to $30 \mathrm{~cm}$ for subsoiler equipped with rotor. Arvidsson et al. (2004) indicated that specific resistance of 
chisel plough, in clay loam soil and $22 \%$ M.C., decreased from 154 to $150 \mathrm{kN} \mathrm{m}^{-2}$ as operating depth increased from 13 to $17 \mathrm{~cm}$. Adding wings have also noticeable effect on specific resistance. In this context, Ahmed and Godwin (1983) found reduction in specific resistance by $17.460 \%$ at $36 \mathrm{~cm}$ operating depth when adding wings width of $30 \mathrm{~cm}$. Olatunji and Davies (2009) carried out an experiment on disc plough in sandy loam soil at 9.4\% M.C., they concluded that specific resistance increased from 17.35 to $34.1 \mathrm{kN} \mathrm{m}^{-2}$ when the forward speed of the implement increased from 0.83 to $1.94 \mathrm{~m} \mathrm{sec}^{-1}$.

In a previous experiment conducted by Ramadan (2011) on a site near the site of this experiment, the oblique subsoiler was evaluated for four operating depths, i.e. 30, 40, 50, and $60 \mathrm{~cm}$ and one forward speed with and without adding wings. But in order to comprehensive assessment for subsoiler performance, this experiment was carried out to investigate the effect of different order of shanks arrangement on subsoiler frame, greater tillage depths, different forward speeds, and with and without adding wings on the draft, disturbed area, and specific resistance.

\section{MATERIALS AND METHODS}

The subsoil plow used for the experiment was manufactured at Machines and agricultural machineries dept. (Fig. 1). The plow is fabricated from locally available materials. The two parallel shanks arrangement is the most common type of the subsoil plow. However, the oblique shanks arrangement is not popular than the previous one.

Subsoil plow may face some problems especially in the heavy soils due to big size of soil clods, high soil penetration resistance and high draft force. Improving performance of subsoil plow by modifying the shape of shanks arrangement on plow's frame as oblique shanks arrangement. Under this arrangement, the right front shank will penetrate the hard (unplowed) soil, while, the left rear shank will penetrate the hard soil from one side (outside) only while the other side (inside) subsoiled with the previous front shank. This operation happens consecutively by contrast the two parallel shanks arrangement which the two parallel shanks penetrates the hard soil at the same time. This means that reducing the total soil resistance on subsoil plow shanks and results in less plowing draft.

The effect of subsoiling speed is significant due to higher draft required by the subsoiler and the availability of appropriate tractor. Selecting suitable speed is important to reduce draft requirement and obtaining maximum performance.

Tractors: Two different tractors namely, a two-wheel drive Massy Ferguson $\left(\mathrm{MF}_{1}\right)$ 285s tractor and a four-wheel drive Massy Ferguson $\left(\mathrm{MF}_{2}\right) 2680$ tractor were used in this study. The $\left(\mathrm{MF}_{1}\right)$ tractor with diesel engine of $51.8 \mathrm{~kW}$ (69.46 hp) (4 cylinders) used as a mobile tractor for tested subsoil plow as the gear shaft was put on idle, while $\left(\mathrm{MF}_{2}\right)$ tractor with diesel engine of $98.33 \mathrm{~kW}$ (131.86 hp) (4 cylinders) was used to pull the $\left(\mathrm{MF}_{1}\right)$ tractor with subsoil plow during measuring draft force under different given testing variables. The draft was measured by using a drawbar dynamometer. It was coupled between two tractors (pull tractor in the front $\left(\mathrm{MF}_{2}\right)$ and mounting subsoil plow tractor in the rear $\left.\left(\mathrm{MF}_{1}\right)\right)$. 
Mesopotamia J. of Agric.

Vol. (42) No. (1) 2014
ISSN: 2224-9796 (Online)

ISSN: $1815-316$ X (Print)

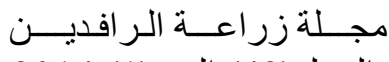

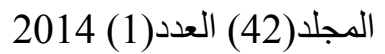
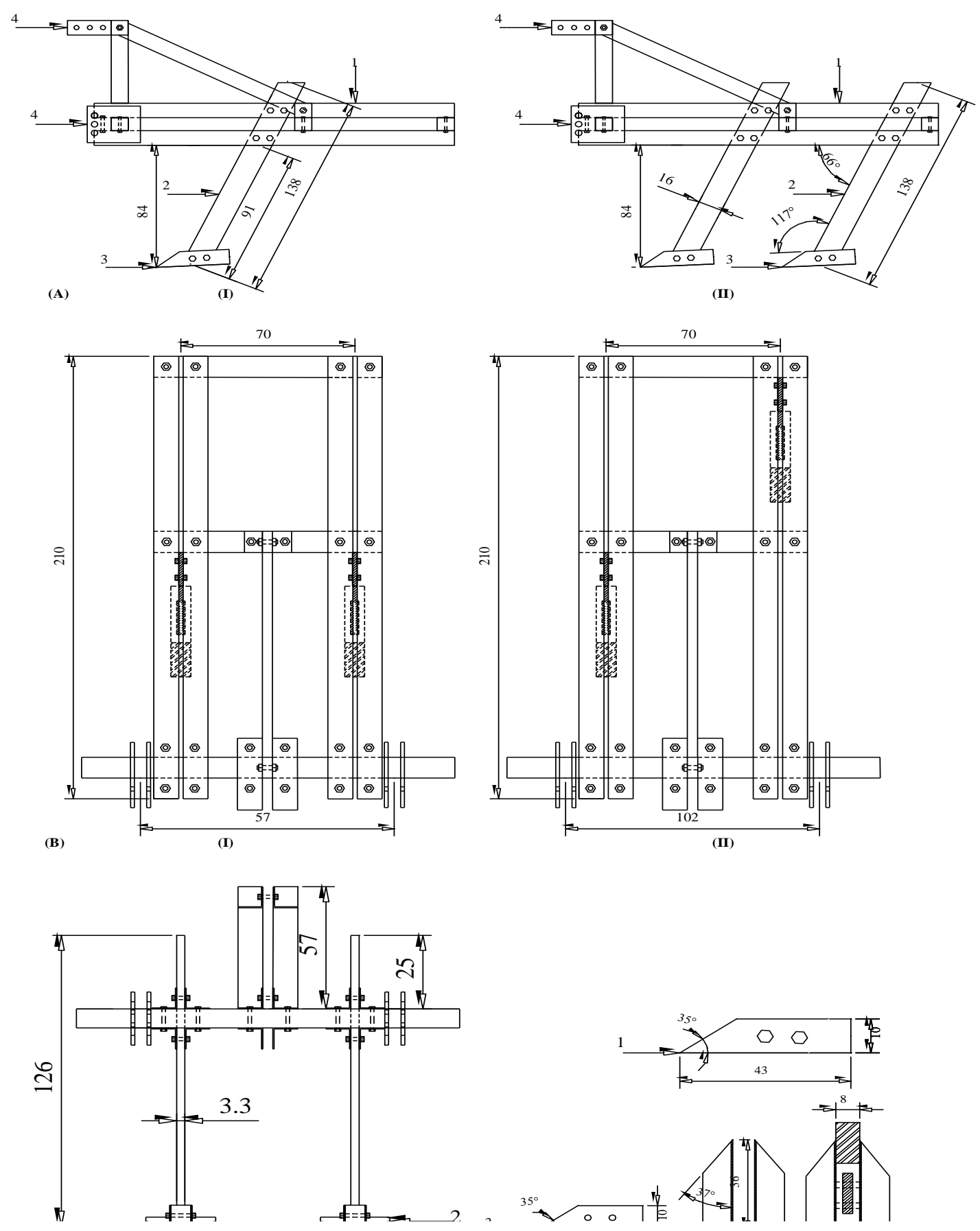

leg. 3) Foot. 4) Hitch points. B. Top view I) Paralle. II) Oblique. C) Front view . D) Side and top view for the wings. 1) foot. 2) wing.

Figure (1): The subsoiler used in the experiment : A Side view I) parallel.II) oblique.1) frame.2) leg.3) foot.4) hitch points. B.top view I) paralle.II) oblique.C) front view . D) side and top view for the wings. foot.2) wing. 
Rolling resistance: Rolling resistance is the force required to pull both of the tractor and subsoil plow in the lifted position over the tested soil. It is a proportional to equipment weight (Hunt, 1983). Estimating the rolling resistance of the tractor is necessary to calculate the net plowing draft force required for the subsoil plows at forward speeds. The rolling resistance of a tractor equipped with mounted subsoil plow determined at no load, while the plowing draft force was determined during subsoiling operation. Rolling resistance was recorded by the draft drawbar dynamometer (4 replicates) and the mean was calculated. The draft of implement was then calculated as the difference between the measured draft and the rolling resistance values.

Disturbed area: The disturbed soil was then manually excavated from the subsoiled zone. Four independent measurements of the area of the subsoiled zone have been done for each treatment. Care was taken to remove only soil loosened by subsoiler. The shape of excavated zone was rounded to geometric shapes in order to facilitate the process of calculating the subsoiled zone (Fig. $2 \& 3$ ). The disturbed area was calculated than by the following formula:

$A=(d \times w)+(s \times d c)$

Where:

$A=$ The disturbed area $\left(\mathrm{m}^{2}\right)$

$d=$ Operating depth $(\mathrm{m})$

$w=$ Trench width under critical depth (m)

$s=$ Length of the disturbed area on shank's sides (m)

$d c=$ Distance between soil surface and critical depth (m)

$b=$ Width of the disturbed area $(\mathrm{m})$

$d d=$ Distance between critical depth and trench bottom $(\mathrm{m})$

$A_{w}=\frac{b+w i}{2} \times d$

Where:

$A_{W}=$ The disturbed area for the winged subsoiler $\left(\mathrm{m}^{2}\right)$

$d=$ Operating depth $(\mathrm{m})$

wi= Width of trench bottom $(\mathrm{m})$

$b=$ Upper width of the disturbed area (m)

Specific resistance: The plow specific resistance is influenced by the width and depth of the tillage (Godwin, 2007). This force was calculated using the following equation:

$$
\text { S.R. }=\frac{F}{A}
$$

Where:

$S . R .=$ Specific resistance $\left(\mathrm{kN} \mathrm{m}^{-2}\right)$

$F=$ Draft force $(\mathrm{kN})$

$A=$ The disturbed area $\left(\mathrm{m}^{2}\right)$ 


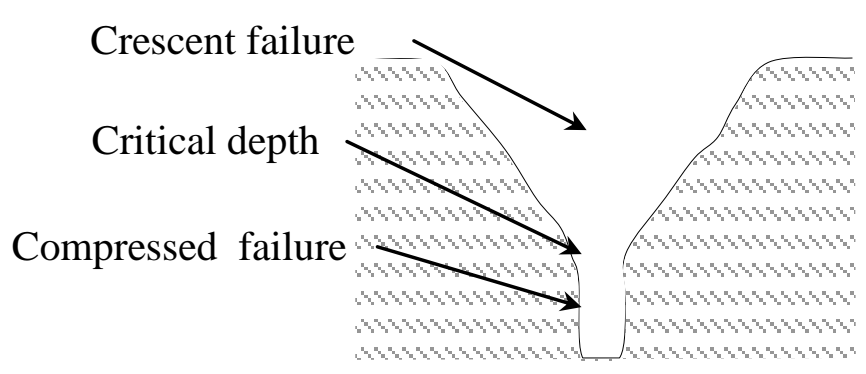

(1)

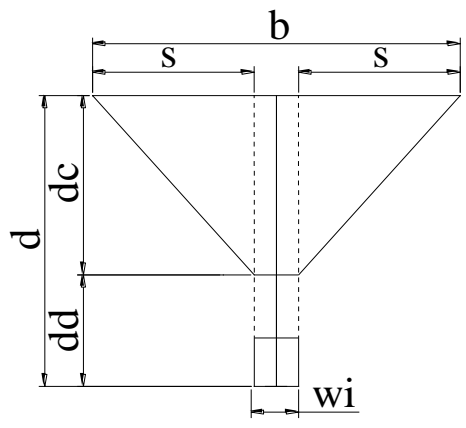

(2)

Figure (2) : The disturbed area for the subsoiler shank. 1) actual profile. 2) theoretical profile.

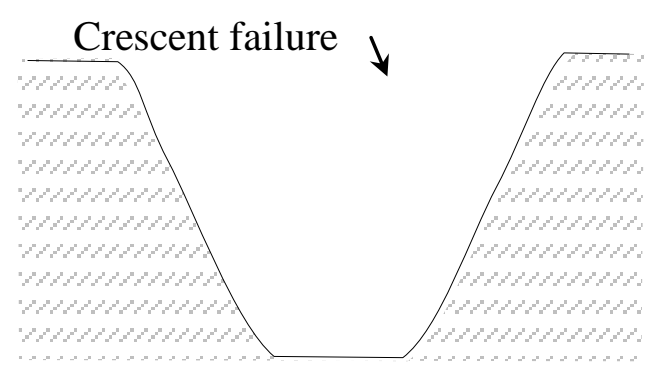

(1)

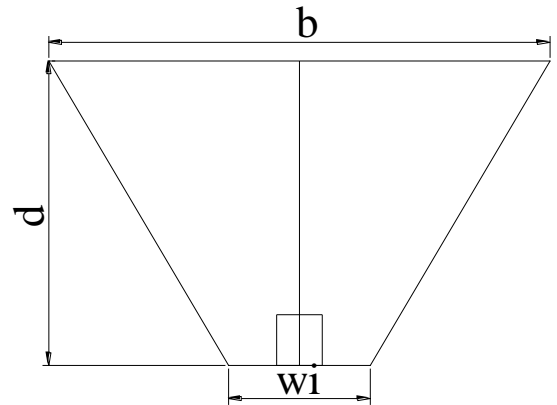

(2)

Figure (3): The disturbed area for the winged subsoiler shank. 1) actual profile. 2) theoretical profile.

Determining forward speed: The pulling $\left(\mathrm{MF}_{2}\right)$ tractor speed determined by measuring ground distance of $30 \mathrm{~m}$ and let the tractor moving and measure the time required to pass this distance. The speed of the tractor was calculated by dividing the distance over the time.

Soil properties: The soil moisture contents of each sample were carried out at laboratory, using an electric oven adjusted to $105^{\circ} \mathrm{C}$ for 24 hours. Soil samples were taken at different soil depths immediately before plowing. Five soil samples (3 replicates for each sample) from the experimental field were collected for each 10 $\mathrm{cm}$ through soil profile. The moisture content of each sample was calculated on a percent dry weight basis using the Black et al. (1993) method by the following formula:

$$
M C \%=\frac{W_{w e t}-W_{d r y}}{W_{d r y}} \times 100 \text {. }
$$

Where:

$M C=$ moisture content $(\%)$

$\mathrm{W}_{\text {wet }}=$ The weight of the wet soil sample $(\mathrm{g})$

$\mathrm{W}_{\text {dry }}=$ The weight of the dried soil sample $(\mathrm{g})$

Five soil samples from the experimental field were collected through the depth $(0-65 \mathrm{~cm})$ and analyzed to obtain the soil texture, liquid and plastic limit (Black et al. 1993). The average of the obtained data were summarized in table (1).

Soil bulk density was measured using samples obtained by cores method. These cores were $5 \mathrm{~cm}$ in diameter and $100 \mathrm{~cm}^{3}$ in volume (Blake and Hartge, 1986). The soil samples were taken randomly. The data was compiled and 
individual values were averaged for each $10 \mathrm{~cm}$ depth. Soil bulk density was calculated by using the following formula:

$\rho b=\frac{m s}{v t}$

Where:

$\rho b=$ The dry bulk density $\left(\mathrm{g} \mathrm{cm}^{-3}\right)$

$m s=$ The weight of the dried soil sample $(\mathrm{g})$

$v t=$ The total volume of the soil sample $\left(\mathrm{cm}^{3}\right)$

A penetrometer was used, with $0.0192 \mathrm{~m}$ cone diameter and $30^{\circ}$ angle cone tip based on ASAE standard $\left(1999^{\mathrm{b}}\right)$, to calculate soil penetration resistance for the undisturbed soil. For the disturbed soil a penetrometer was used with $0.02815 \mathrm{~m}$ cone diameter and $35^{\circ}$ angle. CI was calculated by the using the following formula (Roozbeh et al., 2010):

C.I. $=\frac{F}{A}$.

Where:

C.I. $=$ The cone index $\left(\mathrm{kN} \mathrm{m}^{-2}\right)$

$F=$ The average of recorded forces $(\mathrm{kN})$

$A=$ The CI base area $\left(\mathrm{m}^{2}\right)$

Cohesion and angle of internal friction were measured by using annuals ring. Three replicates were averaged for each $10 \mathrm{~cm}$ depth using the Gill and Vandenberg (1968) method by the following formula:

$\tau=\frac{3 m}{2 \pi \cdot r^{3}}$

Where:

$\tau=$ The soil shear stress $\left(\mathrm{kN} \mathrm{m}^{-2}\right)$

$m=$ The soil shear torque $(\mathrm{kN} . \mathrm{m})$

$\mathrm{r}=$ Radius of the disk $(\mathrm{m})$

The normal stress on soil was calculated from the following formula:

$\sigma=\frac{Q}{A_{d}}$

Where:

$\sigma=$ The soil normal stress $\left(\mathrm{kN} \mathrm{m}^{-2}\right)$

$Q=$ Weight (the sled plate + added weight) $(\mathrm{kN})$

$A_{d}=$ Disk area $\left(\mathrm{m}^{2}\right)$

The relationship between soil shear stress and normal stress was drown. The cohesion and angle of internal friction was determined from the chart.

The adhesion and metal-soil friction angle was measured using sled plate test by the following formula:

$\tau_{h}=\frac{F}{A_{p}}$

$\tau_{h}=$ The horizontal stress $\left(\mathrm{kN} \mathrm{m}^{-2}\right)$

$F=$ The pull force (weight of the sled plate + added weight $)(\mathrm{kN})$

$A_{p}=$ Sled plate contact area $\left(\mathrm{m}^{2}\right)$

The normal stress on soil was calculated from the following formula:

$\sigma=\frac{Q}{A_{p}}$

Where: 
$\sigma=$ The soil normal stress $\left(\mathrm{kN} \mathrm{m}^{-2}\right)$

$Q=$ Weight (the sled plate + added weight) $(\mathrm{kN})$

$A_{p}=$ Sled plate contact area $\left(\mathrm{m}^{2}\right)$

The relationship between soil shear stress and normal stress was also drown.

The adhesion and metal-soil adhesion angle was determined from the chart.

Table (1): Physical and mechanical properties of the experimental field soil.

\begin{tabular}{|c|c|c|c|c|c|c|c|c|c|c|c|c|}
\hline \multirow{3}{*}{$\begin{array}{l}\text { Depth } \\
\mathrm{cm}\end{array}$} & \multirow{3}{*}{$\begin{array}{l}\text { M.C. } \\
\%\end{array}$} & \multicolumn{2}{|c|}{ C.I. } & \multirow{3}{*}{$\begin{array}{l}E \\
\%\end{array}$} & $C$ & $C_{\alpha}$ & \multirow{3}{*}{$\begin{array}{c}\rho b \\
\mathrm{Mg} \mathrm{m}^{-3}\end{array}$} & \multirow{3}{*}{$\begin{array}{l}\phi \quad \delta \\
\text { degree }\end{array}$} & \multirow[t]{3}{*}{ Sand } & \multirow{3}{*}{$\frac{\text { Silt }}{\mathrm{g} \mathrm{kg}^{-1}}$} & \multirow[t]{3}{*}{ Clay } & \multirow{3}{*}{ Texture } \\
\hline & & UCU & $\mathrm{CU}$ & & \multirow{2}{*}{\multicolumn{2}{|c|}{$\mathrm{kN} \mathrm{m}^{-2}$}} & & & & & & \\
\hline & & \multicolumn{2}{|c|}{$\mathrm{kN} \mathrm{m}^{-2}$} & & & & & & & & & \\
\hline 0_10 & 10.631 & 1076.83 & 116.23 & 45.84 & 5.63 & 0.24 & 1.305 & $23 \quad 33.26$ & 159.8 & 542.1 & 298.0 & SCL \\
\hline 10_20 & 11.764 & 3051.02 & 119.38 & 45.09 & 7.21 & & 1.345 & 19 & 129.4 & 532.7 & 337.8 & SCL \\
\hline 20_30 & 13.418 & 3589.44 & 128.80 & 44.08 & 9.05 & & 1.401 & 22 & 116.5 & 553.6 & 329.7 & SCL \\
\hline 30_40 & 17.295 & 5204.68 & 133.51 & 43.39 & 10.20 & & 1.441 & 24 & 128.6 & 512.1 & 359.2 & SCL \\
\hline 40_50 & 19.195 & 5743.10 & 144.51 & 42.72 & 11.51 & & 1.481 & 28 & 117.1 & 513.1 & 369.6 & SCL \\
\hline 50_60 & 21.230 & 5563.63 & 147.65 & 42.46 & 12.21 & & 1.497 & 26 & 105.3 & 522.4 & 372.2 & SCL \\
\hline \multirow{2}{*}{\multicolumn{4}{|c|}{ Liquid limit (\%) }} & c limit & & & & & & & & \\
\hline & & & & 25.86 & & & & & & & & \\
\hline
\end{tabular}

SCL: Silty clay loam. UCU: Un cultivated. CU: Cultivated.

The experiment design: A factorial randomized complete block experiment was the statistical method used for investigation of tillage depth, forward speed and adding wings effects on implement draft, disturbed area and specific resistance. The operating depth was used as (A) factor in 4 levels $(35,45,55$ and $65 \mathrm{~cm})$, speed as (B) factor in 3 levels $\left(0.341,0.551\right.$ and $\left.0.761 \mathrm{~m} \mathrm{sec}^{-1}\right)$ and adding wings as (C) factor in 2 levels (without wings, wings). An ANOVA was constructed using a probability level of 0.05 . The subsoil plow shanks arranged in 2 levels (parallel, oblique). A t-test was conducted to test the null hypothesis that no differences existed between the shanks arrangement means that affected by the studded parameters using a probability level of 0.05 . The statistical analysis conducted by using IBM SPSS Statistics 19 software. Path Analysis was used to examine causal relationships and understand comparative strengths of direct and indirect relationships among variables based on standardized coefficients (SD) (Schumacker and Lomax 1996). Experiments were conducted with four replications (R). An experimental block of $30 \mathrm{~m}$ long and $5 \mathrm{~m}$ wide was used for each treatment. A block of approximately $5 \mathrm{~m}$ long was used as a practice area prior to the beginning of the experimental runs to enable the tractor and the implement to reach the required forward speed and tillage depth.

Table 2: Path coefficients.

\begin{tabular}{llcc}
\hline & & & Estimate \\
\hline Draft & $<---$ & Depth & 0.753 \\
Draft & $<---$ & Speed & 0.130 \\
Draft & $<---$ & Wing & 0.416 \\
Draft & $<---$ & Shanks & 0.485 \\
Area & $<---$ & Depth & 0.739 \\
Area & $<---$ & Speed & -0.115 \\
Area & $<---$ & Wing & 0.634 \\
Area & $<---$ & Shanks & 0.047 \\
S.R. & $<---$ & Depth & -0.510 \\
S.R. & $<---$ & Speed & 0.324 \\
S.R. & $<---$ & Wing & -0.611 \\
S.R. & $<---$ & Shanks & 0.341 \\
\hline
\end{tabular}




\section{RESULTS AND DISCUSSION}

1-Draft force: Statistical analysis of draft requirement by using t-test in spss software clearly showed significant differences between plow shanks arrangement on draft force $(\mathrm{p}<0.01)$ (Fig. 4). Comparison of draft requirement for both shanks arrangement showed that draft saving of $25.517 \%$ could be achieved by using oblique shanks arrangement. This is contributed to penetrating the soil by the front shank first, while, the rear shank penetrates the hard soil from one side (outside) only while the other side (inside) subsoiled with the previous front shank. Accordingly reducing the total soil resistance on subsoil plow shanks and results in less plowing draft. In addition, The parallel shanks break the soil in the form of large size blocks, leading to congregate soil blocks before the shanks and not to pass between the shanks easily, thereby increasing the draft force to push and break the soil blocks, on the contrary the oblique shanks disturb the soil in the form of smaller blocks making it easier to pass between the shanks. Figure 4 shows the draft requirements for both shanks arrangement.

The effect of operating depth on draft force shown in fig. (5). The draft force increased with an increase in operating depth $(\mathrm{p}<0.01)$. increasing operating depth from 35 to $65 \mathrm{~cm}$ increased the draft force by 18.979 and $20.163 \mathrm{kN}$ for oblique and parallel subsoiler respectively. Increasing the operating depth increased the bulk density, cohesion, penetration resistance and moisture content (Tab.1). This is led to higher soil resistance and increasing soil shears strength, in addition more volume of soil handled with increase in depth. Similar finding was observed by Godwin and Spoor (1977), Desbiolles et al. (1997), and Ramadan (2011).

With respect to the effect of adding wings (Fig. 6), The draft force increased significantly $(\mathrm{p}<0.01)$ with adding wings. It could be seem that the highest values of draft force $36.168 \mathrm{kN}$ were obtained when using subsoiler outfitted with wings. While, the lowest values of draft force $28.097 \mathrm{kN}$ were obtained when using subsoiler without wings at any given operating depth under study. This is due to increase surface area for the foot when adding wings and consequently increase in metal-soil friction. In addition increase the disturbed area when adding wings which needs more draft force to disrupt and move the soil. This is in accordance with the results reported by Godwin et al. (1981), Ahmed and Godwin (1983), and Ramadan (2011).

The results show a significant increase in draft in all the treatments with an increase in tractor speed $(p<0.01)$ (Fig. 7). Increasing tractor speed from $s_{1}$ to $s_{3}$ increased the draft from 30.586 to $33.668 \mathrm{kN}$. This is mainly because of the acceleration of the soil. Greater forces provide this acceleration and since they also increase the reaction at the interface, a higher sliding resistance results. The increased sliding resistance contributes most to the increased draft force (Spoor, 1969, Grisso et al., 1996, Chen et al. 1997, and kichler et al. 2008).

The operating depth, however, had bigger effect on the draft than the tractor speed. The results of path analysis (Tab.2) indicated that increasing operating depth led to increase the draft by $0.75 \mathrm{SD}$, while increased by $0.13 \mathrm{SD}$ as the forward speed increase. Increasing operating depth led to increase the soil mechanical properties (Tab. 1) which needs more draft than the draft required to accelerate soil clod due to increasing forward speed. This is in accordance with Sahu and Raheman (2006) and may be partially explained by the work of Stafford (1979) which shows 
Mesopotamia J. of Agric.

Vol. (42) No. (1) 2014
ISSN: 2224-9796 (Online)

ISSN: $1815-316$ X (Print)

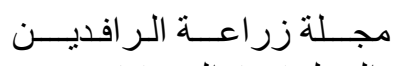

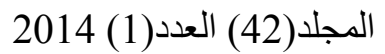

that speed has a smaller effect on draft when the soil fails in a compressive rather than a brittle manner. The result also indicated that shanks arrangement resulting in higher draft compared by adding wing, it was 0.48 and 0.42 SD respectively. This was due to the surface area of the two shanks was largest than the surface area of the wings resulting in higher friction and draft.

The interaction between the depthxwings is not statistically significant (Fig. 8). However, the draft increased with increasing operating depth and adding wings. Also the interaction between the depth $\times$ speed (Fig. 9), speed $\times$ wings (Fig. 10), depth $\times$ speed $\times$ wings (Fig. 11). In all interactions the draft increased with increasing experiment parameters. This was because of the higher soil resistance and more volume of soil handled with increase in depth and adding wings and higher force required to accomplish the soil Acceleration with increase in speed of operation.

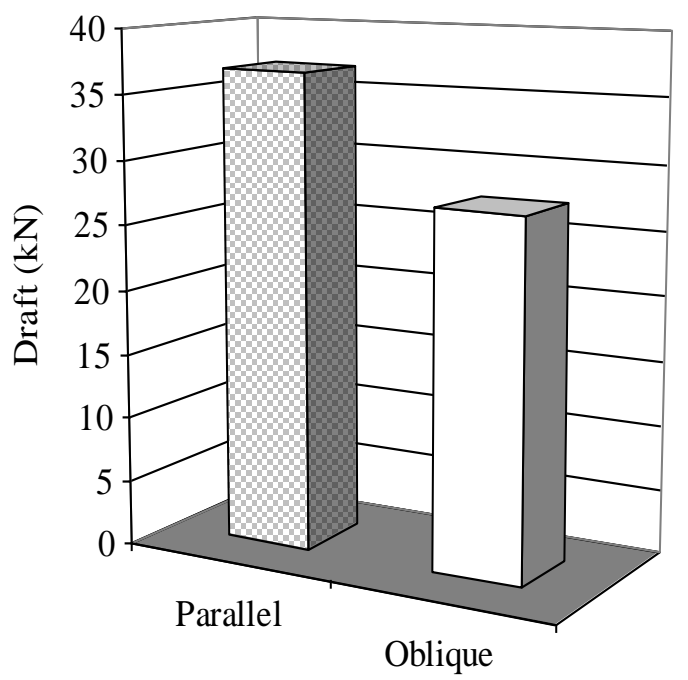

Figure (4): The effect of shanks arrangement on draft force. $\mathrm{T}_{\text {cal. }}=-7.637^{* *} \mathrm{~T}_{\text {tab. }(0.05,190)}=$ 1.972

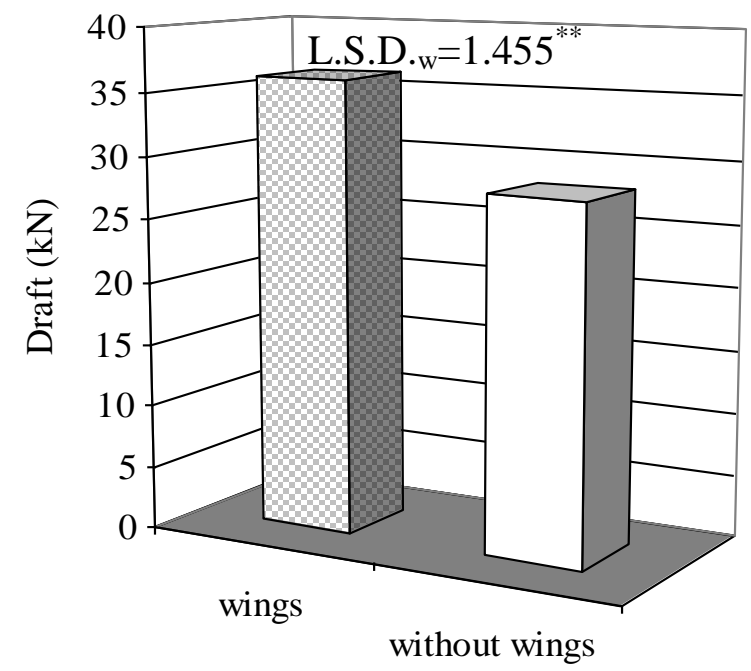

Figure (6): The effect of adding wings on draft force.

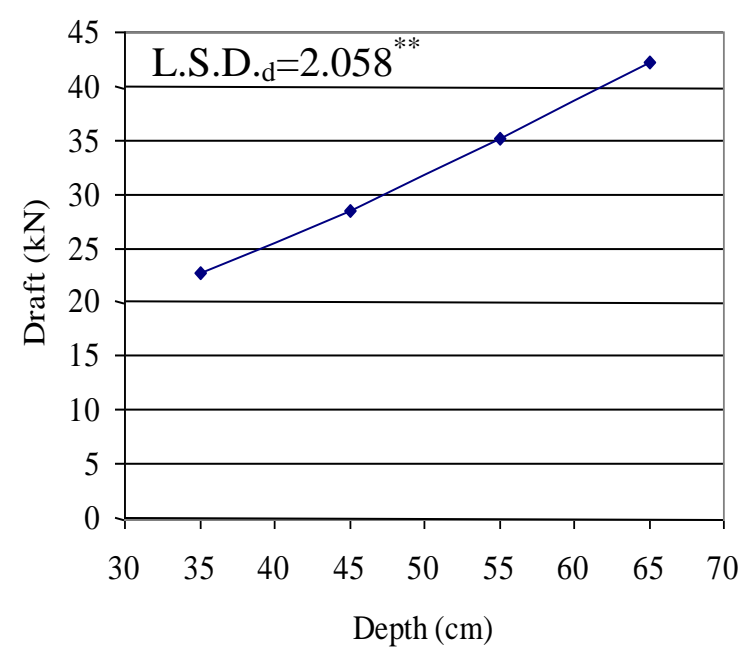

Draft $=0.0036 d^{2}+0.2967 d+7.9541$
$R^{2}=0.98$

Figure (5):The effect of depths on draft force.

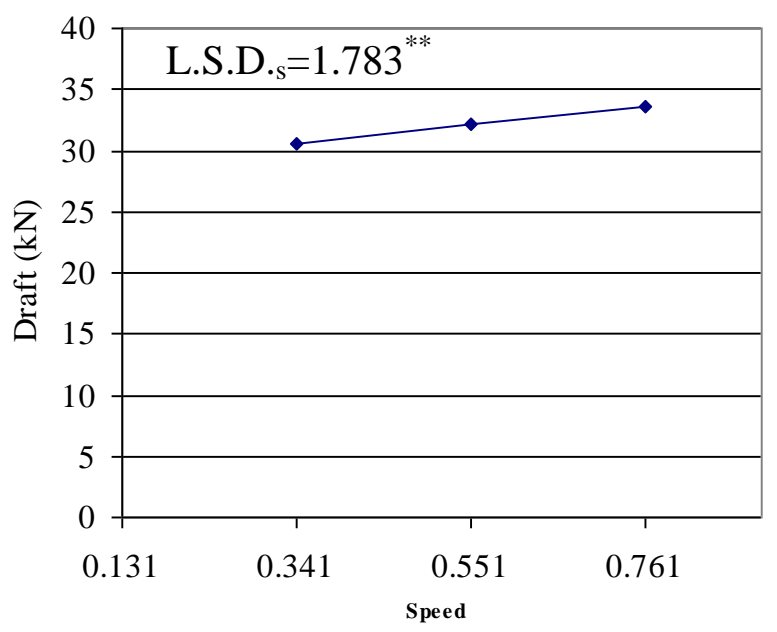

Draft $=-0.3827 \mathrm{~s}^{2}+7.7587 \mathrm{~s}+27.985$

Speed $\mathrm{m} \mathrm{sec}^{-1}$

Figure (7): The effect of speeds on draft force. 
Mesopotamia J. of Agric.

Vol. (42) No. (1) 2014
ISSN: 2224-9796 (Online)

ISSN: $1815-316$ X (Print)

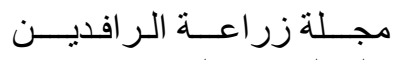
المجلد(42) العدد(1) 2014 اعرن

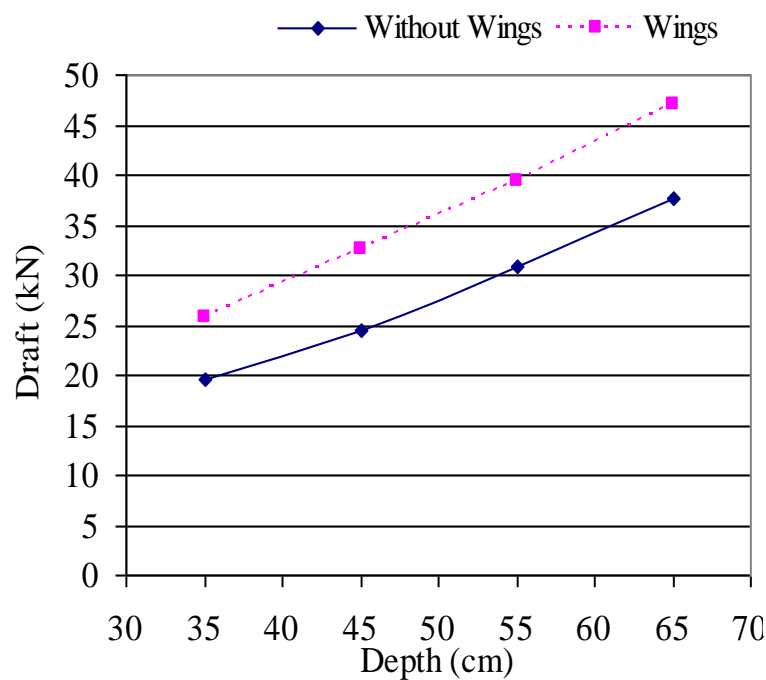

Draft Without Wings $=0.0049 \mathrm{~d}^{2}+0.1097 \mathrm{~d}$

$$
\begin{gathered}
+9.6192 \\
\mathrm{R}^{2}=0.9997
\end{gathered}
$$

Draft Wings $=0.0022 \mathrm{~d}^{2}+0.4837 \mathrm{~d}+6.2891$

$$
\mathrm{R}^{2}=0.9998
$$

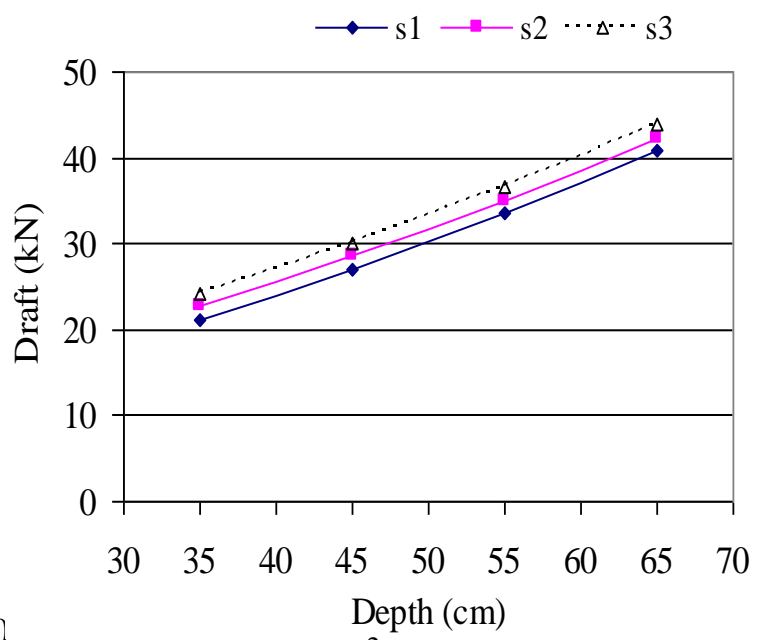

Draft $s_{1}=0.0037 d^{2}+0.2836 d+6.6977$

$$
\mathrm{R}^{2}=0.98
$$

Draft $\mathrm{s}_{2}=0.0033 \mathrm{~d}^{2}+0.3224 \mathrm{~d}+7.3959$

$$
\mathrm{R}^{2}=0.97
$$

Draft $\mathrm{s}_{3}=0.0037 \mathrm{~d}^{2}+0.2841 \mathrm{~d}+9.7688$

$$
\mathrm{R}^{2}=0.98
$$

Figure (8):The effect of depths and adding Figure (9):The effect of depths and speeds on wings on draft force. draft force.

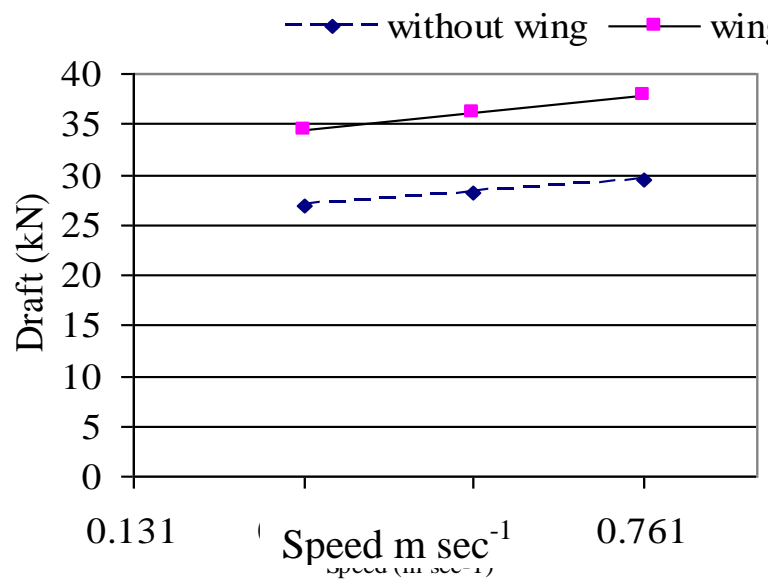

Draft Without Wings $=0.4535 \mathrm{~s}^{2}+5.7859 \mathrm{~s}+24.754 \mathrm{R}^{2}=0.97$

Draft Wings $=-1.3605 \mathrm{~s}^{2}+9.8803 \mathrm{~s}+31.179 \mathrm{R}^{2}=0.98$

Figure (10): The effect of speeds and adding wings on draft force.

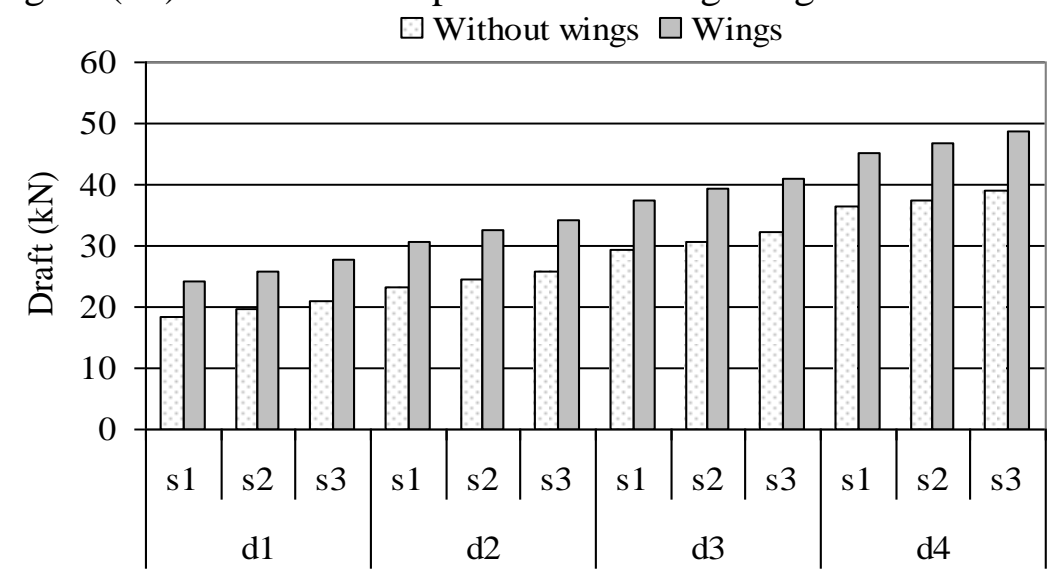

Figure (11):The effect of depths, speeds and adding wings on draft force.

*. Significant at the .05 level. **. Significant at the .01 level. 
2-Disturbed area: The effect of shanks arrangement on disturbed area are indicated in Fig. (12). There was no statistical differences in disturbed area means for the oblique and parallel subsoiler. The disturbed area was 0.3308 and $0.3464 \mathrm{~m}^{2}$ for oblique and parallel subsoiler respectively. The parallel shanks arrangement tend to generate interference crescent failure before the shanks which disturbed the soil in the form of large blocks, which led to this slight increase in the disturbed area.

Significant differences were found in the effect of operating depths on disturbed area $(p<0.01)$ Fig. (13). The disturbed area increased from 0.182 to 0.513 $\mathrm{m}^{2}(181.868 \%)$ when increasing the operating depth from 35 to $65 \mathrm{~cm}$. Increasing the operating depth increased the area of soil that contact with shanks resulting in increased pressure. This enabled the shanks to provide more cracks, taking into consideration the increasing disturbance. The increasing response of disturbed area observed with operating depth is in agreement with McKyes and Maswaure (1997), Al-Suhaibani and Ghaly (2010), and Ramadan (2011).

Similarly adding wings have the same effect on the disturbed area $(\mathrm{p}<0.01)$ Fig. (14). It increased from 0.232 to $0.445 \mathrm{~m}^{2}(91.810 \%)$. It was noted that the soil surface was cracked appreciably due to adding wings, showing the characteristics of lifting up of soil clods during movement of the implement. In addition to increasing the width of cut from the bottom of the trench to the top surface. This trend accords with Spoor and Godwin (1978), Ahmed and Godwin (1983), and Ramadan (2011). The results of path analysis showed that increasing depth by $10 \mathrm{~cm}$ led to increase the disturbed area by 0.73 SD while adding wings led to increase the disturbed area by $0.63 \mathrm{SD}$ (Tab. 2).

The results showed a systematic trend for a slight decreasing of disturbed area as an effect of working speed (Fig. 15). The analysis of variance showed differences in the disturbed area which was highly significant $(p<0.01)$. The disturbed area decreased by $12.912 \%\left(0.047 \mathrm{~m}^{2}\right)$ when the working speed increased from $s_{1}$ to $s_{3}$. Increases the speed of work led to a decrease in the number and length of cracks extending from plow's feet towards the soil surface due to short period of time that the soil being under the stress which reduces the disturbed soil. Stafford (1979) reported an increases in disturbed area with increasing forward speed, this could be due to the forward speeds tested in this research is lower than the speeds that the previous researcher used.

The results also showed that there was significant effect in terms of the depth $\times$ wing interaction $(\mathrm{p}<0.01)$ (Fig. 16), Significant effect was observed either for depth $\times$ speed $(\mathrm{p}<0.01)$ (Fig. 17) and speed $\times$ wing $(\mathrm{p}<0.01)$ (Fig. 18) interaction. No significant difference was observed for depth $\times$ speed $\times$ wing interaction (Fig. 19). However, increasing operating depth, reducing forward speed and using winged subsoiler increased the disturbed area considerably. 
Mesopotamia J. of Agric.

Vol. (42) No. (1) 2014

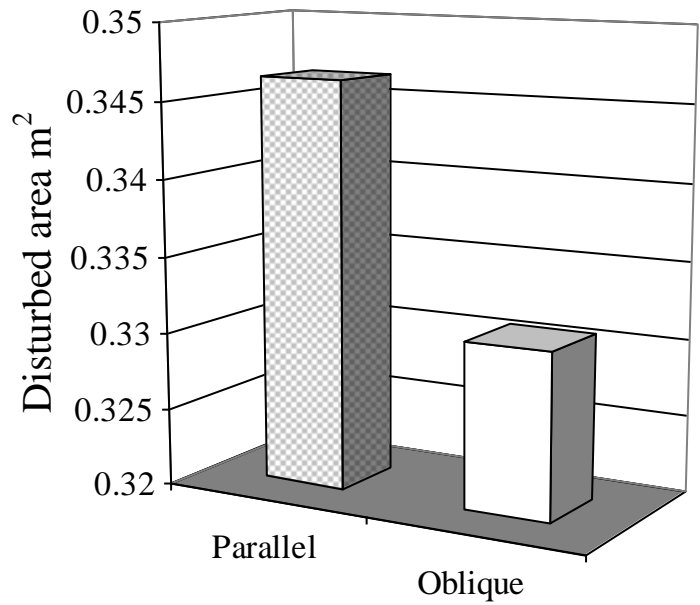

Figure (12) :The effect of shanks arrangement on disturbed area.

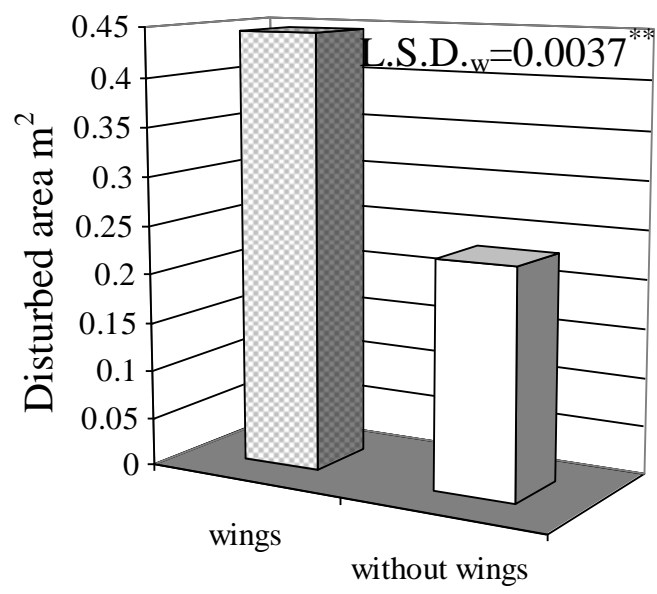

Figure (14):The effect of adding wings on disturbed area.

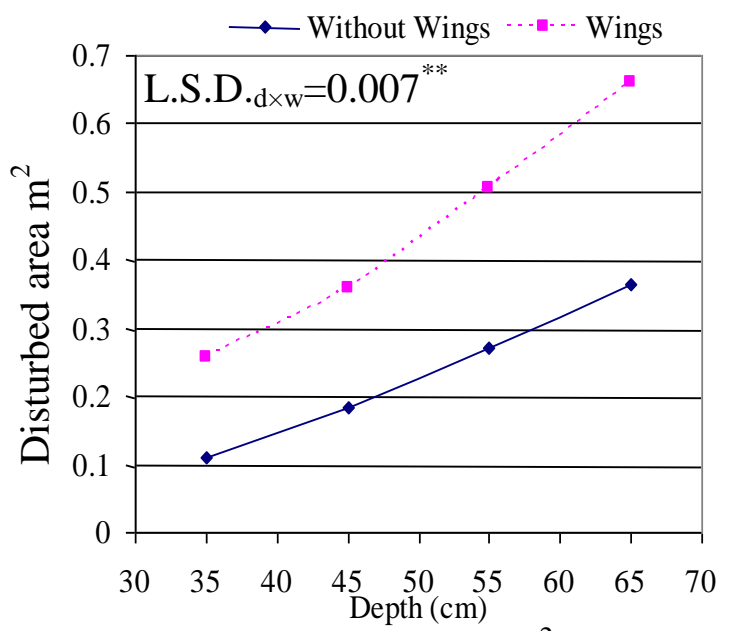

Area Without Wings $=4 \mathrm{E}-05 \mathrm{~d}^{2}+0.0043 \mathrm{~d}$ -

$$
\begin{gathered}
0.0934 \\
\mathrm{R}^{2}=0.9999
\end{gathered}
$$

Area Wings $=0.0001 \mathrm{~d}^{2}+0.0002 \mathrm{~d}+0.0823$

$$
\mathrm{R}^{2}=0.9992
$$

Figure (16):The effect of depths and adding wings on disturbed area.

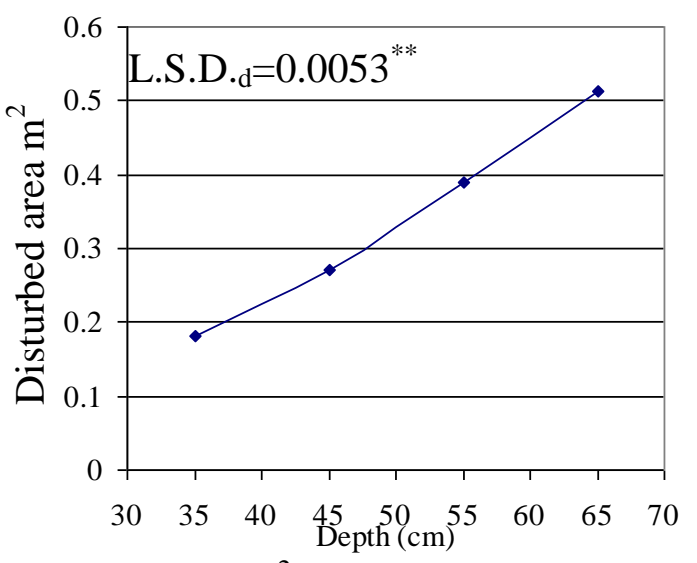

$$
\text { Area }=9 \mathrm{E}-05 \mathrm{~d}^{2}+0.0022 \mathrm{~d}-0.0055 \mathrm{R}^{2}=
$$

0.9995

Figure (13):The effect of depths on disturbed area.

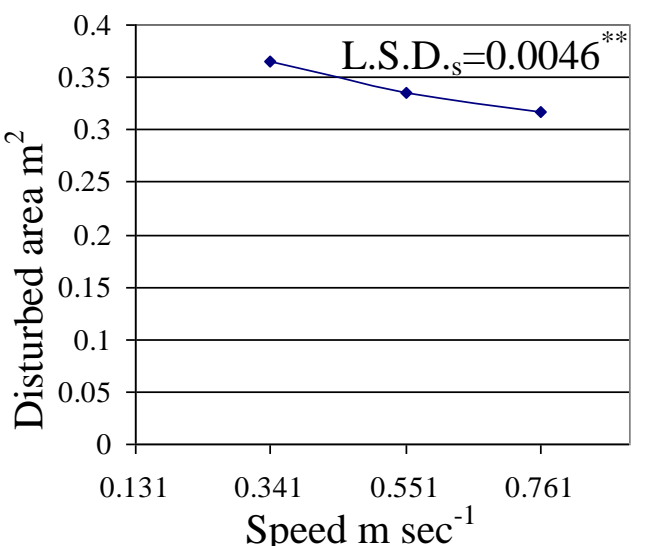

Area $=0.1398 s^{2}-0.2668 s+0.4391 R^{2}=0.97$

Figure (15):The effect of speeds on disturbed area.

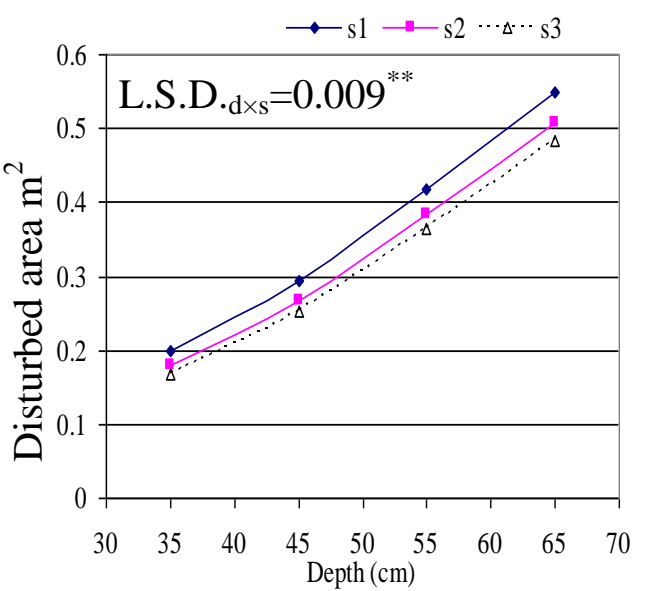

Area $s_{1}=9 E-05 d^{2}+0.0026 d-0.0036 R^{2}=$ 0.9996

Area $s_{2}=9 E-05 d^{2}+0.0024 d-0.0107 R^{2}=$ 0.9995

Area $s_{3}=9 E-05 d^{2}+0.0017 d-0.0023 R^{2}=$ 0.9995

Figure (17):The effect of depths and speeds on disturbed area. 


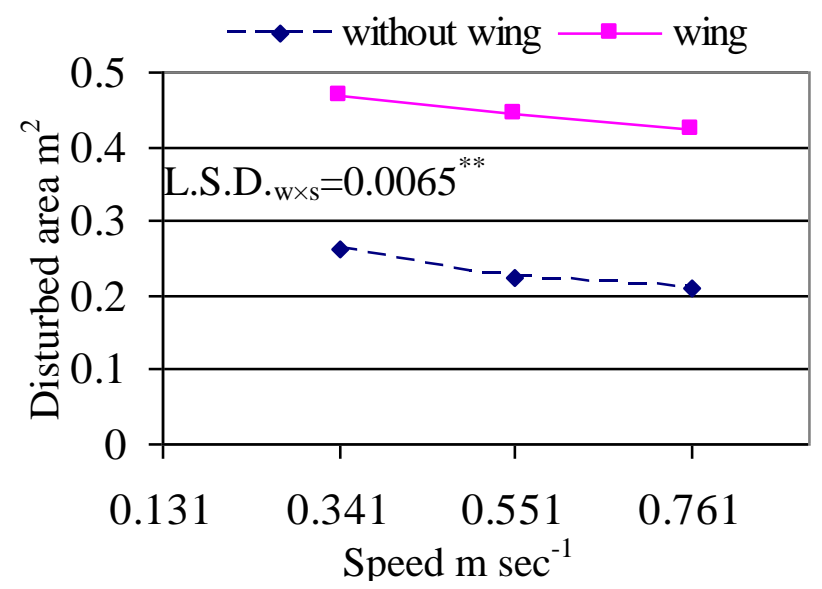

Area Without Wings $=0.015 \mathrm{~s}^{2}-0.1193 \mathrm{~s}+0.5058 \mathrm{R}^{2}=0.98$

Area Wings $=0.2647 \mathrm{~s}^{2}-0.4144 \mathrm{~s}+0.3723 \mathrm{R}^{2}=0.98$

Figure (18):The effect of speeds and adding wings on disturbed area.

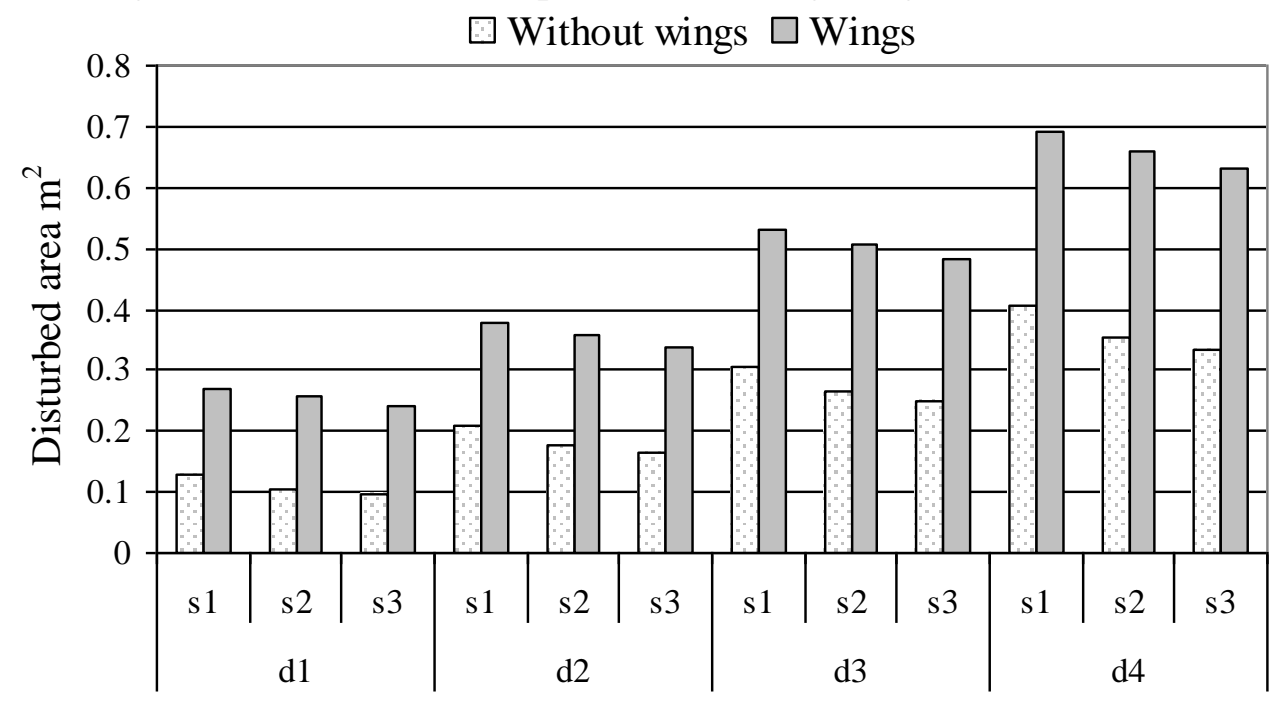

Figure (19):The effect of depths, speeds and adding wings on disturbed area.

*. Significant at the .05 level. **. Significant at the .01 level.

3-Specific resistance: The relationship between specific resistance and shanks arrangement was presented in Fig. 20. It was found from t-test that the specific resistance was significantly $(\mathrm{p}<0.01)$ affected by shanks arrangement. It can also be seen from Fig. 17 that the parallel shanks arrangement experienced higher specific resistance compared to the oblique shanks arrangement $(28.009 \%)$. This was because of more draft requirements for the parallel arrangement as compared to the oblique arrangement associate with slight increase in the disturbed area Fig. (12).

The operating depths had a significant effect on the specific resistance $(\mathrm{p}<0.01)$. Fig. 21 showed that increasing operating depth from 35 to $65 \mathrm{~cm}$ decreased the specific resistance by $62.148 \%$. Increasing operating depth increased the disturbed area by averaged value grater than that of draft which led to lower specific resistance. This is in accordance with the results reported by Misao (1992), Arvidsson et al. (2004), and Ramadan (2011).

Fig. 22 shows the relationship between specific resistance vs. adding wings. The results revealed that the significant effect of adding wings to subsoiler feet on specific resistance $(\mathrm{p}<0.01)$. The specific resistance decreased by $56.423 \%$ with adding wings. This was due to higher disturbed area manipulated by wings associated with lower increase in draft. The effects of adding wings on the specific 
resistance are similar to the results obtained by Spoor and Godwin (1978), Ahmed and Godwin (1983), and Ramadan (2011).

Adding wings have more effect on the specific resistance than that of shanks arrangement at any given depth and speed of operation. The results of path analysis revealed that specific resistance decreased by -0.611 SD when the wings were used, whereas decreased by $-0.341 \mathrm{SD}$ when the oblique arrangement was used instead of parallel arrangement. This was due to increasing of the surface area of the foot and thus the width of cut. This leads to increase the disturbed area by more than the increase in the draft.

It was also observed that adding wings had a greater impact than increasing the depth of sub-soiling (Tab. 2). The winged subsoiler decreased the specific resistance by $-0.61 \mathrm{SD}$ and it decreased by $-0.51 \mathrm{SD}$ as the operating depth increased by $10 \mathrm{~cm}$, this was due to increased draft by $0.753 \mathrm{SD}$ as the operating depth increased by $10 \mathrm{~cm}$ while it increased by $0.416 \mathrm{SD}$ as the wings was added.

It was found from the relationship plotted in Fig. 23 that the effect of tractor speed on specific resistance was significant $(\mathrm{p}>0.01)$. Increasing tractor speed from $s_{1}$ to $s_{3}$ increased the specific resistance by $33.629 \%$. This results could be attributed to higher draft requirement (Fig 7) and the gradual decrease in the disturbed area of soil (Fig 15) which were affected by the tractor speed. Similar results were reported by Olatunji and Davies (2009).

A significant operating depth $\times$ adding wings interaction was found for specific resistance $(\mathrm{p}<0.01)$ (Fig. 24). Increasing operating depth and outfitted the subsoiler with wings increased the disturbed area substantially accompanied by a lower amount of the increase in draft force which led to lower specific resistance.

The interaction of operating depth and foreword speed on specific resistance are shown in Fig 25. There was a significant effect $(\mathrm{p}<0.05)$ on specific resistance. The highest specific resistance was $166.072 \mathrm{kN} \mathrm{m}^{-2}$ for the interaction treatment $\mathrm{d}_{1} \times \mathrm{s}_{3}$, whereas the lowest specific resistance was $77.470 \mathrm{kN} \mathrm{m}^{-2}$ for the interaction treatment $\mathrm{d}_{4} \times \mathrm{s}_{1}$. Increasing operating depth increased soil physical properties (Table 1) which led to higher draft, in addition to increased draft requirement to accelerate soil clods with increasing foreword speed.

The results of ANOVA also showed significant forward speed xadding wings interaction $(\mathrm{p}<0.01)$ for specific resistance (Fig. 26). The subsoiler without wings at higher forward speed gave the highest value $154.714 \mathrm{kN} \mathrm{m}^{-2}$ while the lowest value was $76.673 \mathrm{kN} \mathrm{m}^{-2}$ for the subsoiler outfitted with wings at lower forward speed. The lowest disturbed area resulting from using the subsoiler without wings, and higher draft required with higher forward speed increased the specific resistance considerably. The interaction of three factors were not significant under 0.05 probability level (Fig. 27), The lowest value was $65.401 \mathrm{kN} \mathrm{m}^{-2}$ for the winged subsoiler working at $65 \mathrm{~cm}$ operating depth at $0.341 \mathrm{~m} \mathrm{sec}^{-1}$ forward speed. 
Mesopotamia J. of Agric.

Vol. (42) No. (1) 2014
ISSN: 2224-9796 (Online)

ISSN: $1815-316$ X (Print)
مجــلـة زر اعـــة الر افديــنـن المجلد(42) العدد(1) 2014

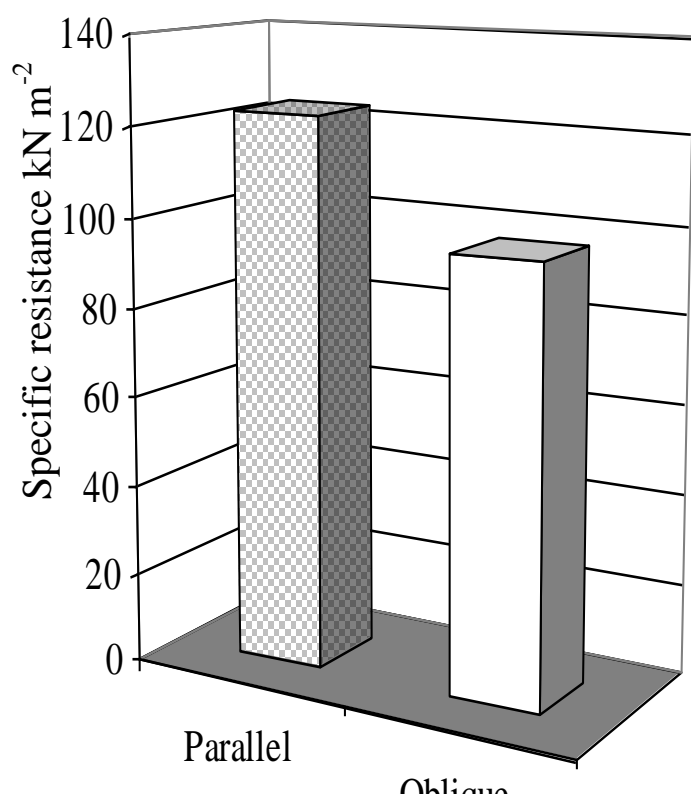

Oblique

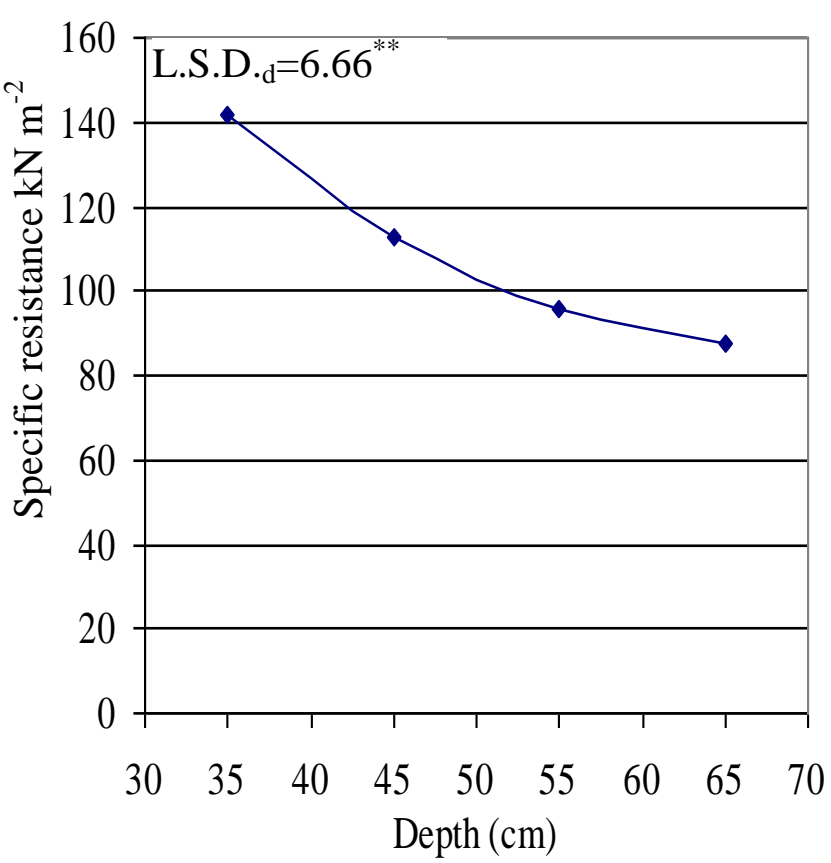

S.R. $=0.0518 d^{2}-6.9786 d+322.56 R^{2}=$ 0.9996

Figure (21):The effect of depths on specific resistance.

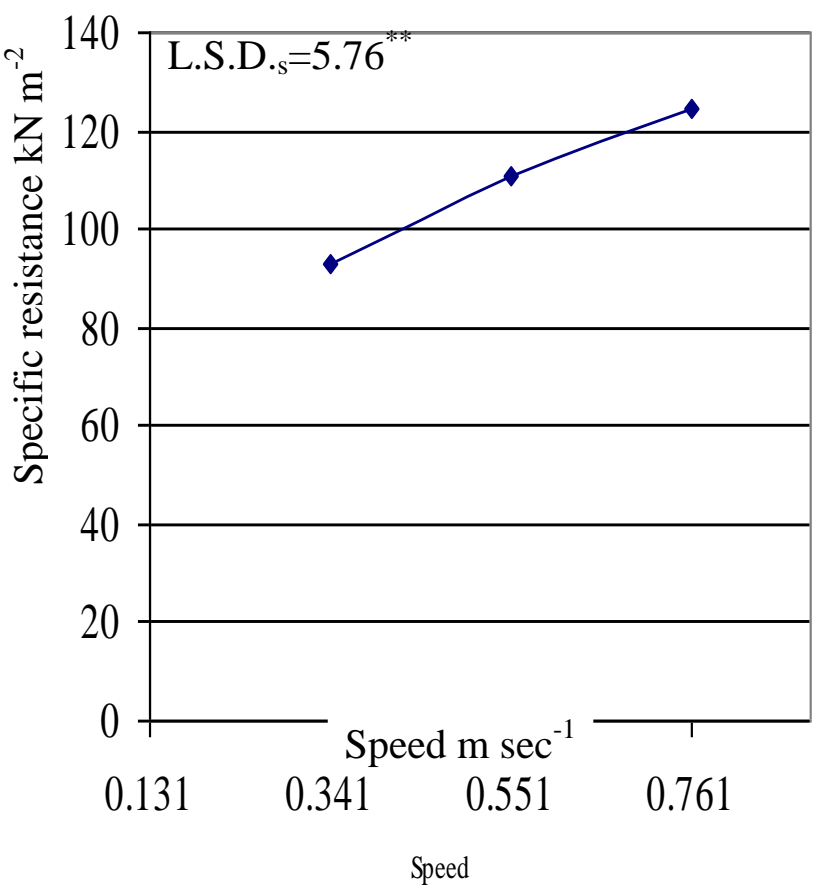
S.R. $=-47.768 \mathrm{~s}^{2}+127.25 \mathrm{~s}+55.342 \mathrm{R}^{2}=$
0.9986

Figure (23):The effect of speeds on specific resistance. 
Mesopotamia J. of Agric.

Vol. (42) No. (1) 2014
ISSN: 2224-9796 (Online)

ISSN: $1815-316$ X (Print)
مجــلة زر اعـــة الر افديــن المجلد(42) العدد(1) 2014

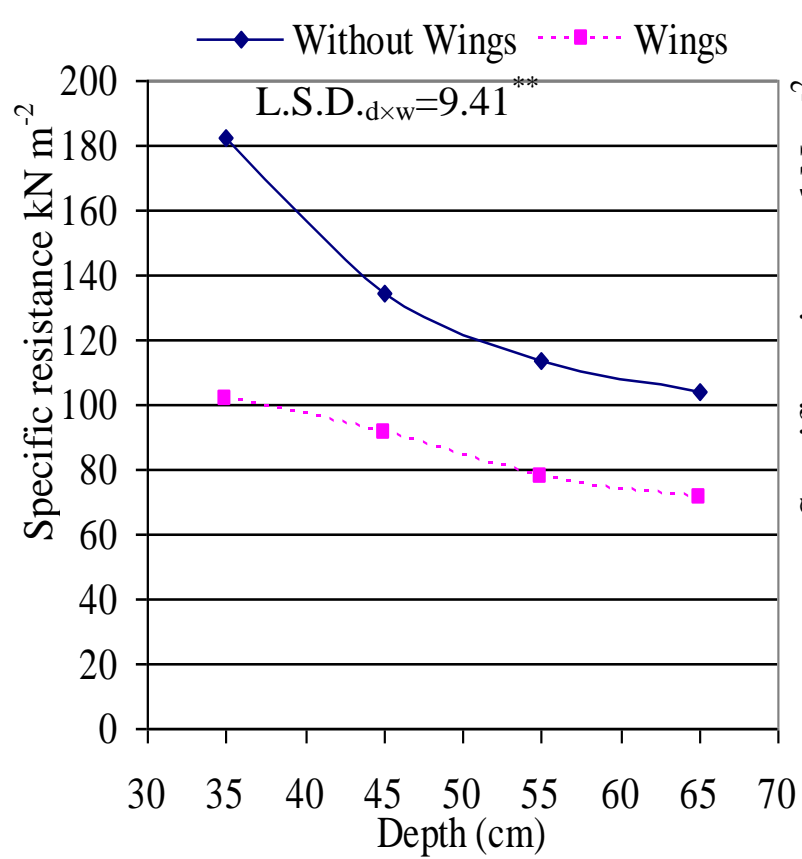

S.R. Without Wings $=0.0958 \mathrm{~d}^{2}-12.135 \mathrm{~d}+$ 489.04

$$
\mathrm{R}^{2}=0.9956
$$

S.R. Wings $=0.0078 \mathrm{~d}^{2}-1.822 \mathrm{~d}+156.08$

$$
\mathrm{R}^{2}=0.9902
$$

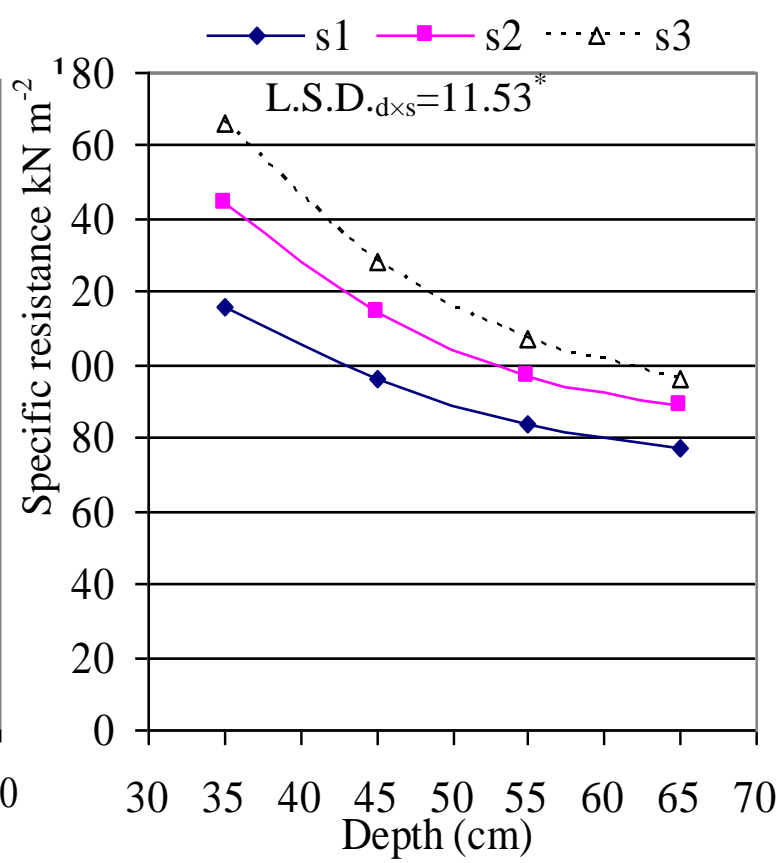

S.R. $s_{1}=0.0334 d^{2}-4.6032 d+235.75$ $\mathrm{R}^{2}=0.9999$

S.R. $\mathrm{s}_{2}=0.054 \mathrm{~d}^{2}-7.2405 \mathrm{~d}+331.14$

$$
\mathrm{R}^{2}=0.9994
$$

S.R. $s_{3}=0.0679 d^{2}-9.0923 d+400.79$

$$
\mathrm{R}^{2}=0.9994
$$

Figure (24):The effect of depths and adding Figure (25): The effect of depths and speeds wings on specific resistance. on specific resistance.

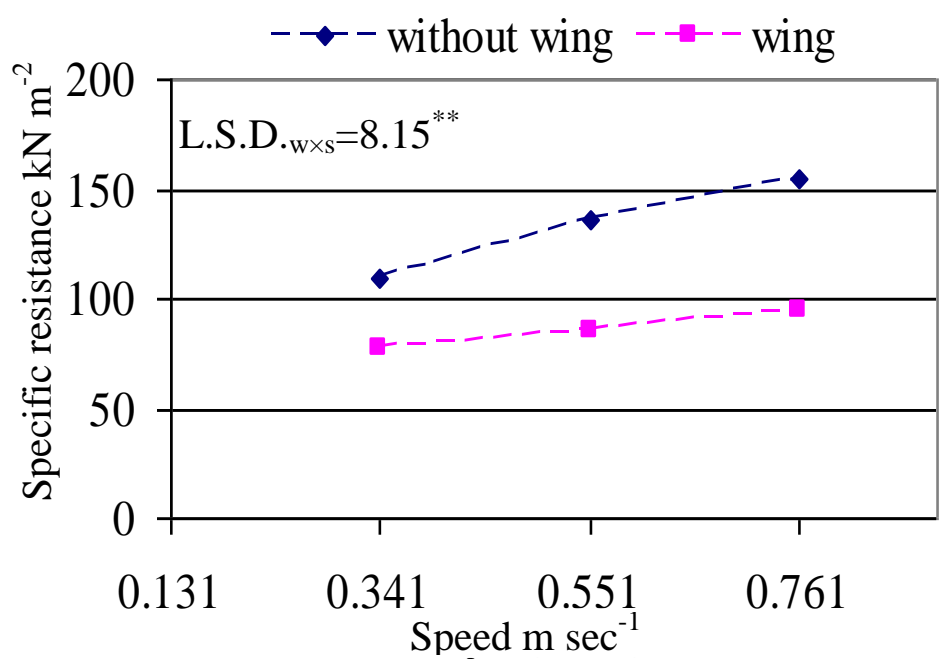

S.R. Without Wings $=-99.773 \mathrm{~s}^{2}+217.09 \mathrm{~s}+47.273 \mathrm{R}^{2}=0.98$ S.R.Wings $=4.5351 \mathrm{~s}^{2}+36.907 \mathrm{~s}+63.587 \mathrm{R}^{2}=0.97$

Figure (26):The effect of speeds and adding wings on specific resistance. 


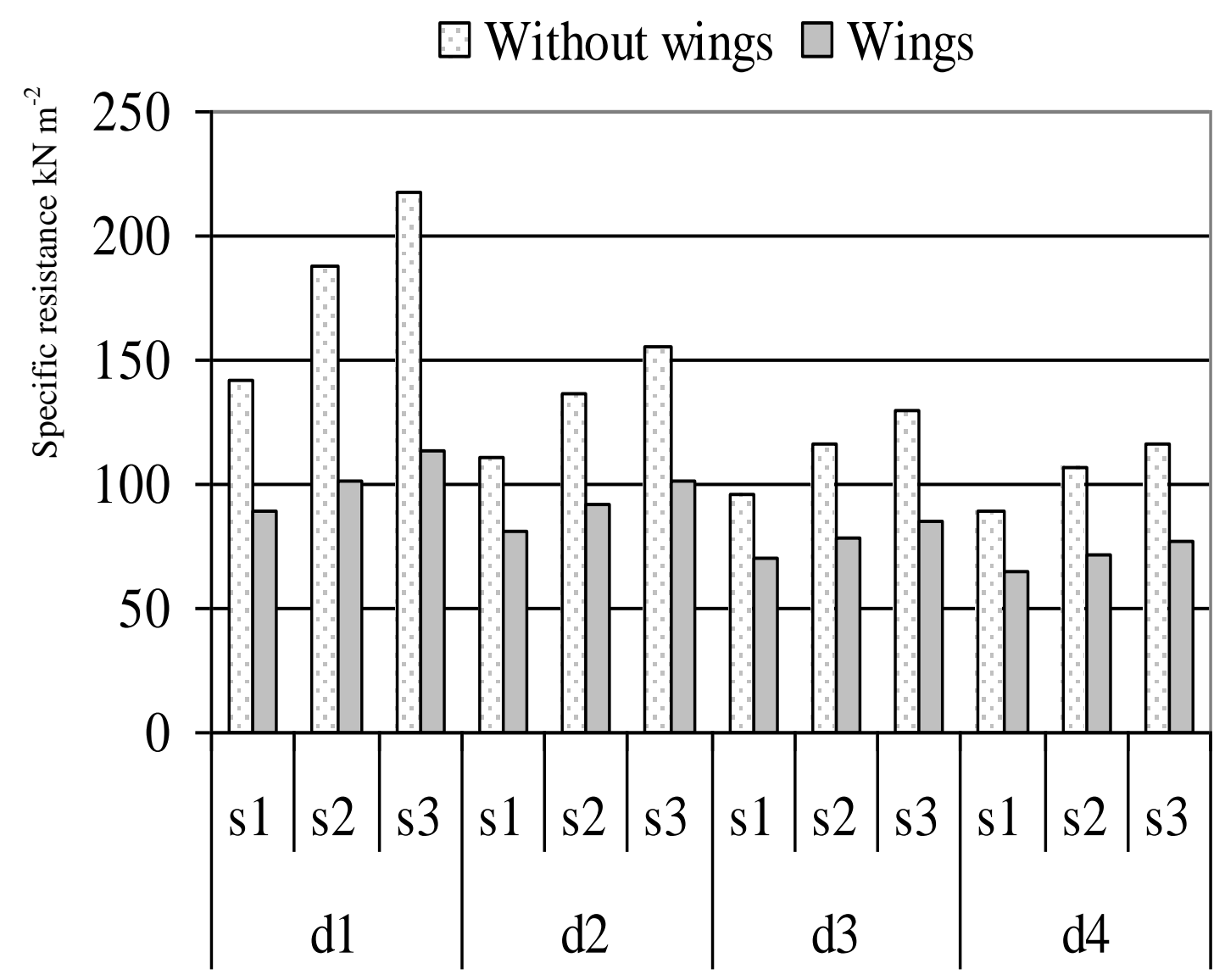

Figure (27): The effect of depths, speeds and adding wings on specific resistance. *. Significant at the .05 level. **. Significant at the .01 level.

Field tests were conducted to determine the effects of shanks arrangement, depth, speed and attachment wings to subsoiler feet on the draft, disturbed area and specific resistance of modified subsoiler in silty clay loam soil. Using the oblique shanks arrangement significantly saved about $(25.517 \%)$ in draft compared with parallel shanks arrangement, in addition to obtain lowest specific resistance (21.880 $\%)$. A significant increase in draft was observed for oblique and parallel shanks arrangement with an increase in operating depth and forward speed. The subsoiler outfitted with wings showed greater draft requirement and disturbed area, and lower specific resistance than the subsoiler without wings for the same depth and range of speed. The results also indicate that draft and specific resistance increased with increasing speed, whereas disturbed area decreased with increasing speed. Decreasing speed from $s_{3}$ to $s_{1}$ decreased draft and specific resistance, while increasing disturbed area. Using oblique shanks arrangement and outfitted feet with wings at lower forward speed gave better performance for any subsoiling depth.

\section{ACKNOWLEDGMENTS}

The author is grateful for assistance provided by Professor Ali H. A. and Mr. Ali. 


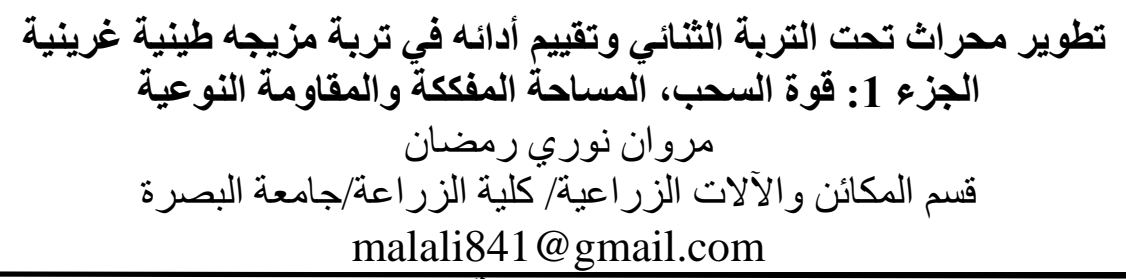

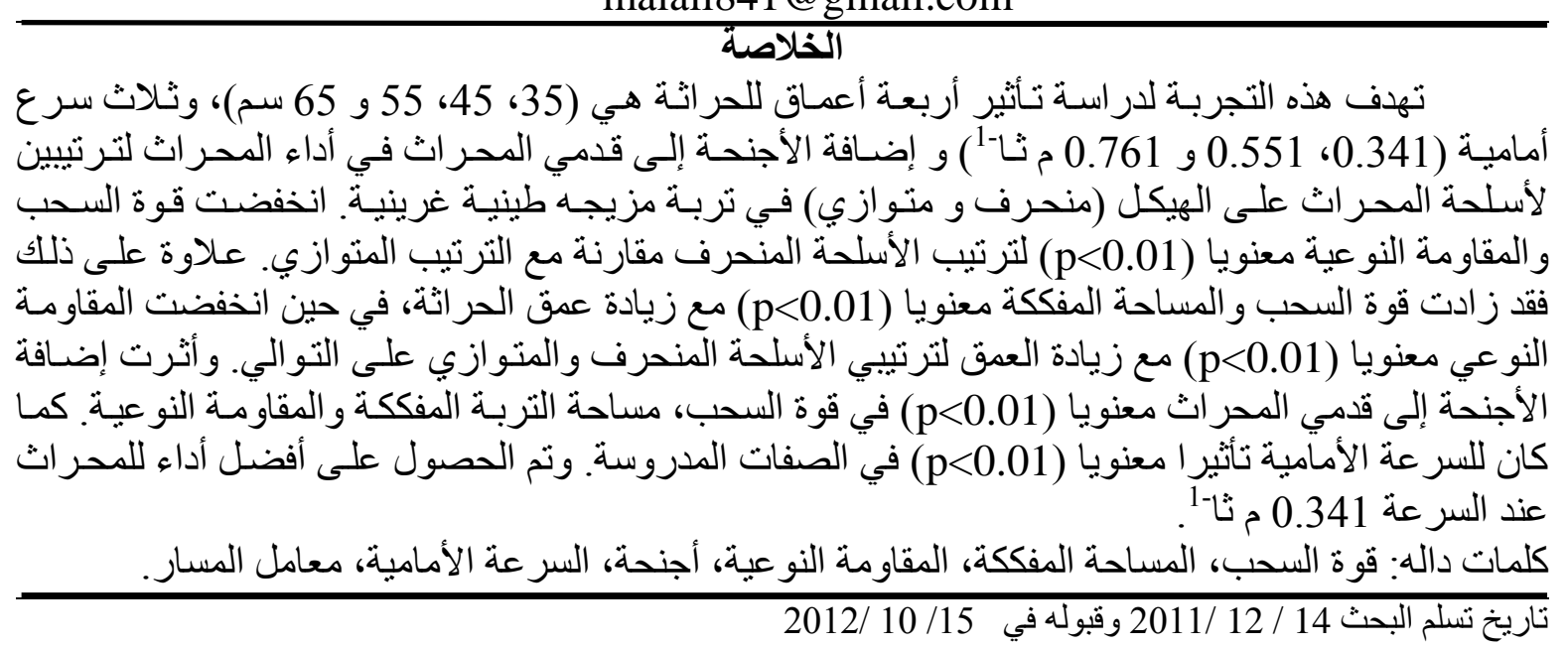

\section{REFERENCES:}

Ahmed, M.H., and R.J. Godwin (1983). The influence of wing position on subsoiler penetration and soil disturbance. Journal Of Agricultural Engineering Research. 28: 489-492.

Al-Suhaibani, S.A. and A.E. Ghaly (2010). Effect of plowing depth of tillage and forward speed on the performance of a medium size chisel plow operating in a sandy soil. American Journal Of Agricultural And Biological Sciences. 5 (3): 247-255.

Anonymous (1999) ${ }^{\mathrm{a}}$. Data ASAE D 230.3: Agricultural Machinery Management Data. Agricultural engineering. Year Book 1982, St. Joseph MI 49085

Anonymous Standards $\left(1999^{\mathrm{b}}\right)$. ASAE S313.3: Soil Cone Penetrometer. Approved Feb., 1999. ASAE St. Joseph, MI.

Arvidsson, J., T. Keller, and K. Gustafsson (2004). Specific draught for mouldboard plough, chisel plough and disc harrow at different water contents. Soil And Tillage Research. 79:221-231.

Black, C.A, J.L. White, L.E. Ensimenger, and F.E. Clark (1993). Method Of Soil Analysis. $6^{\text {th }}$ ed. American Society Of Agronomy, Inc., Pub. Madison. Wisconsin, U.S.A.

Blake, G.R. and K.H. Hartge (1986). Bulk density. In Methods Of Soil Analysis, Klute, A. (Ed.). Part I, $2^{\text {nd }}$ Edn. Agronomy Monographs. 9. ASA and SSSA, Madison, WI., pp: 363-376.

Chen, J.N., J.C. Coquille, J.P. Douzals, F. Andreux and R. Sabre (1997). Frequency composition of traction and tillage forces on a mole plough. Soil And Tillage Research. 44: 67-79.

Desbiolles, J.M.A., R.J. Godwin, J. Kilgour, and B.S. Blackmore (1997). A novel approach to the prediction of tillage tool draught using a standard tine. Journal Of Agricultural Engineering Research. 66:295-309.

Di Prinzio, A.P., C.D. Ayala, and J.C. Magdalena (1997). Energy evaluation of different techniques and subsoiling effects on soil bulk density. Agro-Science 13:61-67. 
Drever, K.W. and E.H. Wiens (1980). Equipment Comparisons For Deep Plowing Solonetzic Soils. The $198060^{\text {th }}$ Annual AIC Conference Canadian Society of Agricultural Engineering. University of Alberta, Edmonton, Alberta. Paper No. 80-409.

Gill, W.R. and G.E. Vanden Berg (1968). Soil Dynamics In Tillage And Traction. Agricultural Handbook. Washington DC: USDA-Agric. Res. Service, pp: 316.

Glancey, J.L., S.K. Upadhyaya, W.J. Chancellor and J.W. Rumsey (1996). Prediction of agricultural implement draught using an instrumented analog tillage tool. Soil And Tillage Research, 37, 47-65.

Godwin, R.J. (2007). A review of the effect of implement geometry on soil failure and implement forces. Soil and Tillage research. 97: 331-340

Godwin, R.J., and G. Spoor (1977). Soil failure with narrow tines. Journal of Agricultural Engineering Research. 22: 213-228.

Godwin, R.J., G. Spoor and P. Leeds-Harrison (1981). An experimental investigation into the force mechanics and resulting soil disturbance of mole ploughs. Journal Of Agricultural Engineering Research. 26: 477-497.

Grisso, R.D., M. Yasin and M.F. Kocher (1996). Tillage implement forces operating in silt clay loam. Transactions Of The ASAE. 39 (6): 1977-1982.

Hunt, D. (1983). Farm Power Machinery Management. English Edition. Iowa State Univ. Press Ames. pp. 3-6.

Iqbal, M., M. Younis, M.S. Sabir and A.H. Azhar (1994). Draft requirements of selected tillage implements. Agricultural Mechanization In Asia, Africa And Latin America. 25 (1): 13-15.

Kichler, C.M., J.P. Fulton, R.L. Raper, W.C. Zech, T.P. McDonald, and E.B. Schwab (2008). Effects of transmission speed on equipment performance and utilizing spatial equipment performance data for management decisions. In D.M. Endale, (ed.) Proc. $30^{\text {th }}$ Southern Conservation. Agricultural Systems. Conference and $8^{\text {th }}$ Annual. Georgia Conservation. Prod. Syst. Trng. Conf., Tifton, GA. July 29-31. SCASC.

Mckyes, E., and J. Maswaure (1997). Effect of design parameters of flat tillage tools on loosening of a clay soil. Soil And Tillage Research. 43: 195-204.

Misao, Y. (1992). Studies on mechanical subsoil breaking (part2). The characteristic failure performance for rotary subsoil breaker with a chisel type subsoiler. Journal Of The Japanese Society Of Agricultural Machinery. 54 (1): 27-37.

Olatunji, O.M. and R.M. Davies (2009). Effect of weight and draught on the performance of disc plough on sandy-loam soil. Research Journal Of Applied Sciences, Engineering And Technology. 1 (1): 22-26.

Palmer, A.L., and I.R. Kruger (1982). Comparative drafts of six tillage implements. In The Proceeding Of The 1982 Conference On Agricultural Engineering, Armidale, NSW Australia, 22-24 August. Barton, Australia, pp: 163-167.

Ramadhan, M.N. (2011). Field Study To Evaluate The Mechanical Performance of The Double Tines Longitudinally Arranged Subsoiler and Its Effect On Some Growth Characteristics of Barley Hordeum vulgare L. MSc. Thesis, College of Agriculture, Basrah University, Iraq.

Roozbeh, M., M. Almasi, A. Hemmat, M. Hedayatizadeh, M. Attashi, M Karimi, and M.G. Varnamkhasti (2010). Soil penetration resistance and time required for corn seedbed preparation under four tillage systems. Journal of Agricultural Technology. 6(2): 211-218. 
Sahu, R.K. and H. Raheman (2006). Draught prediction of agricultural implements using reference tillage tools in sandy clay loam soil. Biosystems Engineering. 94: 275-284.

Schumacker, R.E. and Lomax, R.G. (1996). A Beginner's Guide to Structural Equation Modeling. Mahwah, New Jersey: Lawrence Erlbaum Associates, Publishers.

Spoor, G. (1969). Design of soil engaging implements. Farm Machine Design Engineering. 3, 22-26.

Spoor, G., and R.J. Godwin (1978). An experimental investigation into the deep loosening of soil by rigid tines. Journal Of Agricultural Engineering Research. 23 (3): 243-258.

Stafford, J.V. (1979). The performance of a rigid tine in relation to soil properties and speed . Journal Of Agricultural Engineering Research. 24(1): P 41-56.

Upadhyaya, S.K, T.H. Williams, L.J. Kemble, and N.E. Collins (1984). Energy requirement for chiseling in coastal plain soils. Transactions Of The ASAE. 27(6): 1643-1649. 